\title{
Etanol ve Dimetil Sülfoksidin Çeşitli İnsan Hücre Hatları Üzerindeki in vitro Sitotoksik Etkisi
}

\section{Elif AYAZOGLU DEMIR ${ }^{1}$, Selim DEMIR ${ }^{2}$, Yuksel ALIYAZICIOGLU ${ }^{3}$}

${ }^{1}$ Department of Chemistry, Faculty of Science, Karadeniz Technical University, 61080 Trabzon, ${ }^{2}$ Department of Nutrition and Dietetics, Faculty of Health Sciences, Karadeniz Technical University, 61080 Trabzon, ${ }^{3}$ Department of Medical Biochemistry, Faculty of Medicine, Karadeniz Technical University, 61080 Trabzon, Turkey.

${ }^{1}$ https://orcid.org/0000-0001-9027-7633, ${ }^{2}$ https://orcid.org/0000-0002-1863-6280, ${ }^{3 h t t p s: / / o r c i d . o r g / 0000-0001-9474-4307 ~}$

$\bowtie$ : selim-demir@hotmail.com

\section{ÖZET}

Literatürde etanol ve dimetil sülfoksit (DMSO)'in bazı hücre hatları üzerindeki sitotoksik etkileri gösterilmiş olmasına rağmen, bu çözücülerin melanoma (VMM917), akciğer kanseri (A549), kolon kanseri (WiDr), normal kolon (CCD $841 \mathrm{CoN}$ ) ve fibroblast (BJ) hücreleri üzerindeki sitotoksik etkilerini belirleyen bir çalışma bulunmamaktadır. Bu çalışmanın amacı, etanol ve DMSO'nun yukarıda belirtilen hücrelere ek olarak insan meme (MCF-7), karaciğer (HepG2) ve serviks (HeLa) kanser hücreleri üzerindeki sitotoksik etkilerini belirlemektir. $\mathrm{Bu}$ amaçla, hücreler farklı konsantrasyonlarda $(\% 0.1, \% 0.2, \% 0.4, \% 0.6, \% 0.8, \% 1, \% 2$ ve $\% 4$, hacim/hacim) etanol ve DMSO ile muamele edilmiş ve daha sonra MTT prosedürü uygulanmıştır. Elde edilen sonuçlar, etanol ve DMSO'nun incelenen tüm hücrelerde doza bağlı sitotoksisite sergilediğini göstermiştir. DMSO ve etanole en duyarlı hücreler sırasıyla WiDr ve VMM917 iken, en dirençli hücreler sırasıyla BJ ve A549 olarak belirlenmiştir. Sonuçlar, her bir hücre hattında etanol ve DMSO'nun sitotoksik etki sergilediği konsantrasyon aralığının farklı olduğunu ortaya koymuştur. Yanlış pozitif ve negatif sonuçlara neden olmamak için, hücre kültürü çalışmalarında öncelikle kullanılacak çözücülerin sitotoksik etkilerinin oluşmadığı konsantrasyon aralığı belirlenmelidir.

\section{Araștırma Makalesi}

\section{Makale Tarihçesi}

Geliş Tarihi $\quad: 12.03 .2020$

Kabul Tarihi : 24.04 .2020

\section{Anahtar Kelimeler}

Hücre kültürü

Sitotoksisite

Etanol

Dimetil sülfoksit

MTT metodu

\section{In vitro Cytotoxic Effect of Ethanol and Dimethyl Sulfoxide on Various Human Cell Lines}

\section{ABSTRACT}

Although the cytotoxic effects of ethanol and dimethyl sulfoxide (DMSO) on some cell lines have been shown in the literature, there is no study about the cytotoxic effects of these solvents on common used human cell lines, such as melanoma (VMM917), lung cancer (A549), colon cancer (WiDr), normal colon (CCD $841 \mathrm{CoN}$ ) and fibroblast (BJ) cells. The aim of this study was to determine the cytotoxic effects of ethanol and DMSO on human breast (MCF-7), liver (HepG2) and cervix (HeLa) cancer cells in addition to above mentioned cells. For this purpose, the cells were treated with different concentrations $(0.1 \%, 0.2 \%, 0.4 \%, 0.6 \%, 0.8 \%, 1 \%, 2 \%$, and $4 \%, \mathrm{v} / \mathrm{v})$ of ethanol and DMSO and then subjected to MTT assay. According to the results, ethanol and DMSO exhibited dose-dependent cytotoxicity in all cells studied. The most DMSO and ethanol sensitive cells were WiDr and VMM917, while the most resistant cells were determined as BJ and A549, respectively. The results revealed that the concentration range in which ethanol and DMSO exhibited cytotoxic effect in each cell line is different. In order not to cause false positive and negative results, the concentration range in which the solvents used in cell culture studies do not have cytotoxic effects should be determined.

\section{Research Article}

$\begin{array}{ll}\text { Article History } \\ \text { Received } & : 12.03 .2020 \\ \text { Accepted } & : 24.04 .2020\end{array}$

Keywords
Cell culture
Cytotoxicity
Ethanol
Dimethyl sulfoxide
MTT assay

To Cite : Ayazoglu Demir E, Demir S, Aliyazicioglu Y, 2020. In vitro Cytotoxic Effect of Ethanol and Dimethyl Sulfoxide on Various Human Cell Lines. KSU J. Agric Nat 23 (5): 1119-1124. DOI: 10.18016/ksutarimdoga.vi.702702. 


\section{INTRODUCTION}

For scientific, economic and ethical reasons, cell culture systems have become a widely used laboratory tool in determining the cytotoxicity of a variety of compounds of drug candidate (Forman et al., 1999). These systems allow the investigation of the effects of candidate compounds on cellular functions using stable homogeneous cells (Timm et al., 2013). While it is relatively possible to determine the effects of watersoluble compounds on cells, it is an important problem that the organic solvents used to dissolve apolar compounds may have independent cytotoxic effects on the studied cells (Forman et al., 1999). Organic solvents, such as ethanol, acetone, dimethylformamide and dimethyl sulfoxide (DMSO), are often used to dissolve hydrophobic compounds in cell culture assays due to their strong solubility properties (Jamalzadeh et al., 2016). However, these organic solvents are reported to have cytotoxic effects on various cell types (Forman et al., 1999; Timm et al., 2013). Some studies even show that various cell lines have different sensitivity to the same solvent (Jamalzadeh et al., 2016; Hajighasemi and Tajik, 2017; Yi et al., 2017). Therefore, it is reported that the type and concentration of the used solvent must be determined in such a way as to ensure the solubility of the material being examined without adversely affecting the experimental procedures such as cell growth (Jamalzadeh et al., 2016).

Ethanol is a two-carbon alcohol compound and is frequently used in the dissolving of hydrophobic compounds and preparation of natural product extracts in experimental studies (Jamalzadeh et al., 2016; Misir et al., 2018; Misir et al., 2020). At the cellular level, ethanol is well known to have long-term effects, such as DNA damage and then carcinogenesis, as well as pleiotropic effects that can lead to short-term cytotoxicity (Kade et al., 2016). Dimethyl sulfoxide [DMSO, $\left(\mathrm{CH}_{3}\right)_{2} \mathrm{SO}$ ] is a highly polar organic liquid, widely used as a solvent (Yi et al., 2017). DMSO can dissolve a large number of non-polar and polar small components, increase cell membrane permeability, prevent free radical formation and increase the penetration of pharmaceutical mediators into cells (Hajighasemi and Tajik, 2017). DMSO is generally considered a low toxicity solvent. However, it has been reported that DMSO can induce cytotoxicity in various cells based on the type of cell. The mechanism proposed for DMSO cytotoxicity is explained by its effect on the physical properties of phospholipids in the membrane (Hebling et al., 2015; de Abreu Costa et al., 2017).

Various studies have investigated the cytotoxic effect of ethanol and DMSO on some cell lines. Yeo et al. (2000) demonstrated that ethanol exhibits a dosedependent cytotoxic effect on Swiss 3T3 cells by inhibiting DNA synthesis and protein tyrosine phosphorylation, while $\mathrm{Wu}$ et al. (2010) showed that the DMSO concentrations higher than $4 \%(\mathrm{v} / \mathrm{v})$ exhibits cytotoxic and apoptotic properties in the pheochromocytoma (PC-12) cell line. Timm et al. (2013) reported that ethanol and DMSO have a statistically significant cytotoxic effect on five different human white blood cell lines depending on the cell type. Human melanoma (VMM917), lung (A549) and colon (WiDr) cancer cell lines are frequently used in in vitro experiments as melanoma, lung and colon cancer models, respectively (Gazdar et al., 2010; Berg et al., 2017; Liu et al., 2017). Colon normal (CCD 841 CoN) and fibroblast (BJ) cells are also frequently used cell lines in in vitro genotoxicity, aging and cancer models (Aliyazicioglu et al., 2017; Schäuble et al., 2012; Ferreira et al., 2019). However, to the best of our knowledge, there is no study that determines the concentration-dependent cytotoxic effects of ethanol and DMSO on these five cell lines. The aim of this study was to determine the concentration-dependent cytotoxic effects of ethanol and DMSO on these cell lines for the first time.

\section{MATERIALS and METHOD}

\section{Chemicals}

All chemicals used in cell culture studies were purchased from Lonza (Verviers, Belgium) and Biological Industries (Kibbutz Beit Haemek, Israel). All the chemicals used in the analysis were purchased from Sigma-Aldrich (St. Louis, MO, USA). All solvents used were HPLC grade.

\section{Cell Culture}

Human melanoma (VMM917, CRL-3232), cervix adenocarcinoma (HeLa, CCL-2), breast adenocarcinoma (MCF-7, HTB-22), lung carcinoma (A549, CCL-185), hepatocellular carcinoma (HepG2, HB-8065), colon adenocarcinoma (WiDr, CCL-218), colon normal (CCD 841 CoN, CRL-1790), and normal foreskin fibroblast (BJ, CRL-2522) cells were supplied by the American Type Culture Collection (Manassas, VA, USA). All cells were cultured in Eagle's minimum essential medium (EMEM) supplemented with $10 \%$ heat inactivated fetal bovine serum and 1\% antibiotic solution with a $5 \% \mathrm{CO}_{2}$ supply at $37^{\circ} \mathrm{C}$ (Demir et al., 2018a; Turan et al., 2018).

\section{Cytotoxicity Experiments}

MTT assay with a 72-h treatment time was employed to measure the cytotoxic effects of DMSO and ethanol on various cell lines (Mosmann, 1983). All cancer and CCD $841 \mathrm{CoN}$ cells were seeded into a flat-bottomed 96-well cell culture plates at $1 \times 10^{4}$ cells per well, while BJ cells were seeded at $2 \times 10^{3}$ cells per well (Demir et al., 2019a; Demir et al., 2019b). The cells were then treated with varying concentrations $(0.1 \%, 0.2 \%, 0.4 \%$, 
$0.6 \%, 0.8 \%, 1 \%, 2 \%$, and $4 \%$, v/v) of DMSO and ethanol for $72 \mathrm{~h}$ (Casañas-Sánchez et al., 2016). Cisplatin was used as a positive control in cytotoxicity experiments to show that the experimental setup was working correctly (Turan et al., 2017; Demir et al 2018b). Subsequently, $10 \mu \mathrm{L}$ of MTT dye $\left(0.25 \mathrm{mg} \mathrm{mL}^{-1}\right)$ was placed inside each well. The crystals that formed were then dissolved in DMSO. Finally, absorbance was measured using a microplate reader (Molecular Devices Versamax, California, USA) at $570 \mathrm{~nm}$. Optical densities were employed to calculate percentage viabilities in treated cells compared to untreated control cells. Log-concentrations versus \%cell viabilities were plotted with a logarithmic graph, which was then used to determine the $\mathrm{IC}_{50}$ values (Aliyazicioglu et al., 2019; Demir et al., 2020).

\section{Statistical Analysis}

All experiments were performed four times, the results being expressed as mean \pm standard deviation. Normal distribution was determined using the KolmogorovSmirnov test. One-Way ANOVA was used to analyze intergroup differences. $\mathrm{p}<0.05$ was regarded as significant.

\section{RESULTS and DISCUSSION}

Cell culture systems are widely used to determine in vitro effects of drugs and natural product extracts (Timm et al., 2013). Drugs or natural products whose effects are investigated are usually made soluble with organic solvents. Therefore, when working with waterinsoluble compounds and it is imperative to determine the range of concentration in which the organic solvent used for each cell group has a cytotoxic effect (Forman et al., 1999). DMSO and ethanol are two of the most used organic solvents in cell culture studies (Jamalzadeh et al., 2016), and there are limited studies about their own cytotoxicity on only some cell lines, such as Swiss 3T3, PC-12, Mono Mac 6, HL-60 and RAW 264.7 (Yeo et al., 2000; Wu et al., 2010; Timm et al., 2013). While VMM917, A549, WiDr, CCD 841 CoN and $\mathrm{BJ}$ cell lines are common used cell lines in in vitro experiments as cancer, aging and genotoxicity models, (Gazdar et al., 2010; Schäuble et al., 2012; Aliyazicioglu et al., 2017; Berg et al., 2017; Liu et al., 2017; Ferreira et al., 2019), there is no study that determines the concentration-dependent cytotoxic effects of ethanol and DMSO on these cell lines. In this study, it was therefore aimed to determine the concentration-dependent cytotoxic effects of DMSO and ethanol on these cell lines in addition to MCF-7, HepG2 and HeLa cell lines. The cytotoxic effect of ethanol and DMSO was evaluated using MTT assay, which is a is a non-radioactive, quick, and affordable method (Demir et al., 2018b) and cell viability percentages are shown in Figures 1 and 2.

The results showed that DMSO and ethanol had cytotoxic effects on the all studied cells in a dosedependent manner. When all cells are evaluated together, statistically significant cytotoxic effect of DMSO and ethanol was emerged starting at a concentration of $0.2 \%(\mathrm{v} / \mathrm{v})$ and $0.4 \%(\mathrm{v} / \mathrm{v})$, respectively. Interestingly, the statistically significant cytotoxic effect of ethanol on A549 cell line was only seen starting at a concentration of $2 \%(\mathrm{v} / \mathrm{v})$. In order to make the results more understandable, the $\mathrm{IC}_{50}$ values of DMSO and ethanol in all studied cell lines were calculated and presented in Table 1.

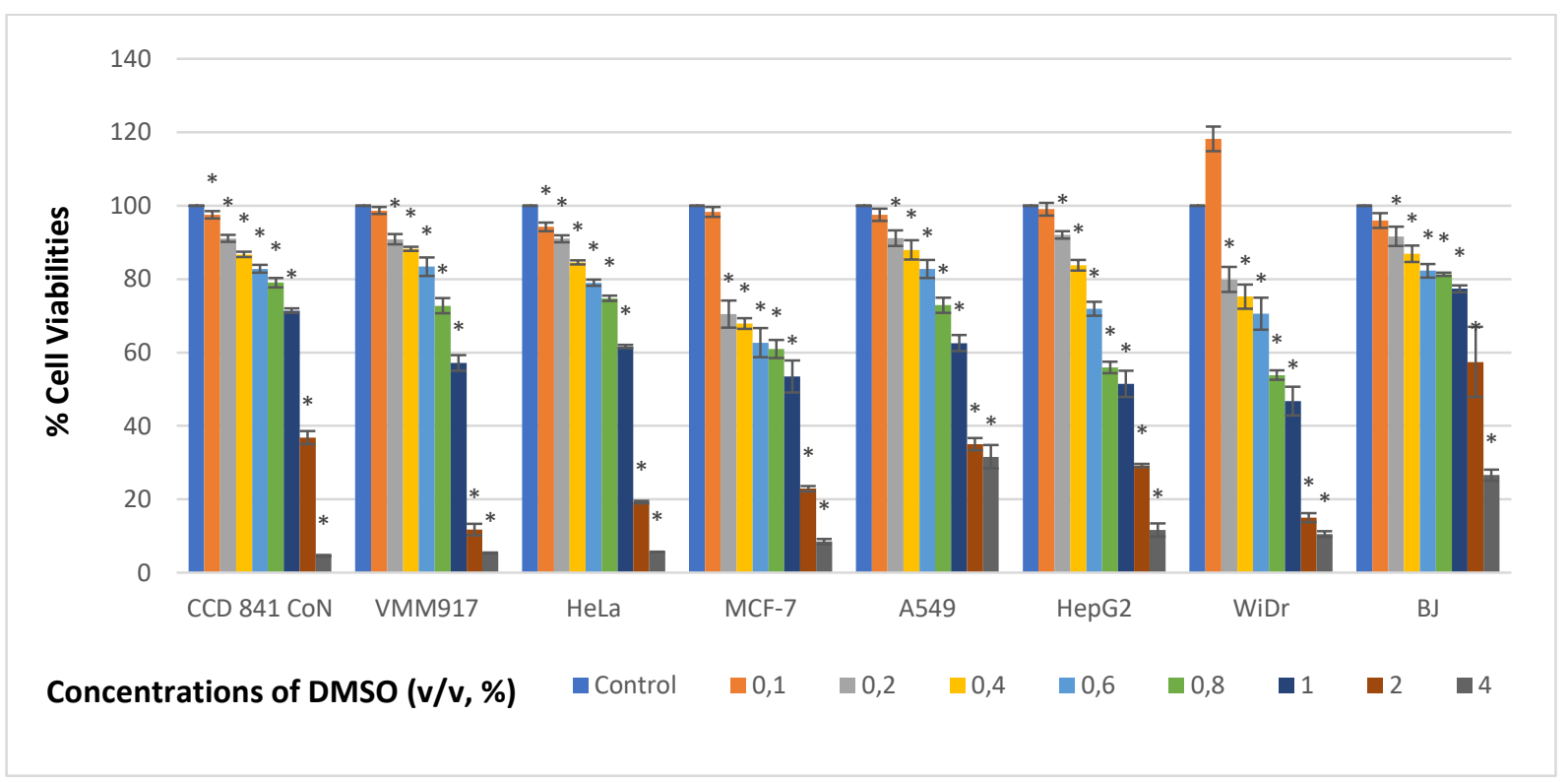

Figure 1. Effect of DMSO on viability of human cell lines. *Represents statistically significant, $\mathrm{p}<0.05$. Şekil 1. DMSO'nun insan hücre hatları canlılı̆ğ üzerindeki etkisi. “istatistiksel olarak anlamlı farkı gösterir, $p<0.05$. 


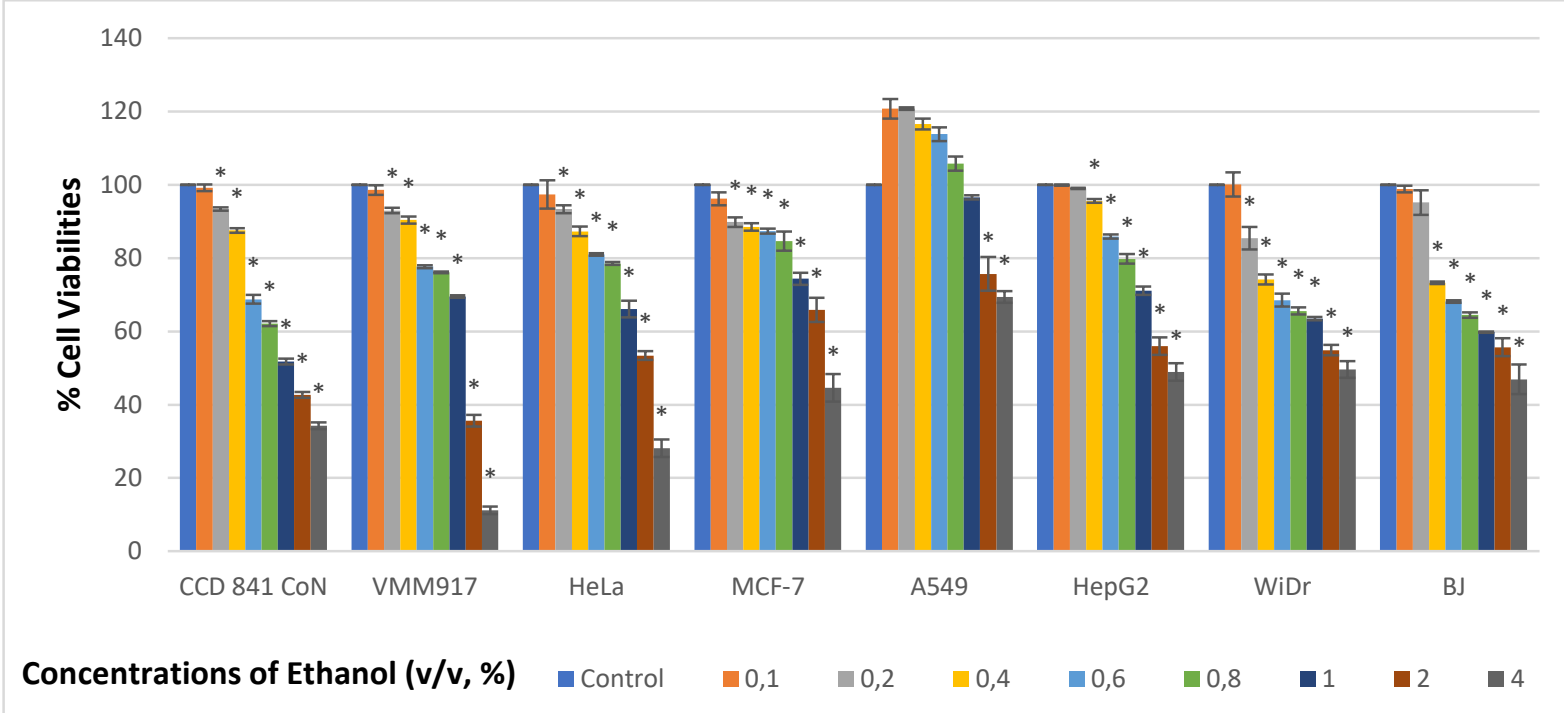

Figure 2. Effect of ethanol on viability of human cell lines. *Represents statistically significant, $\mathrm{p}<0.05$. Şekil 2. Etanolün insan hücre hatları canlılı̆̆ üzerindeki etkisi. ${ }^{*}{ }^{\prime}$ statistiksel olarak anlamlı farkı gösterir, $p<0.05$.

Table 1. $\mathrm{IC}_{50}$ values $(\% \mathrm{v} / \mathrm{v})$ calculated for ethanol and DMSO on different cell lines $(\mathrm{n}=4)$ Cizelge 1. Farklı hücre hatlarında etanol ve DMSO için hesaplanan IC $C_{50}(\%)$ değerleri $(n=4)$

\begin{tabular}{cccc}
\hline & Ethanol & DMSO & Cisplatin $(\mu \mathrm{g} / \mathrm{mL})$ \\
\hline VMM917 & $1.41 \pm 0.04$ & $1.08 \pm 0.07$ & $0.70 \pm 0.01$ \\
HeLa & $2.15 \pm 0.13$ & $1.09 \pm 0.01$ & $0.76 \pm 0.04$ \\
MCF-7 & $3.35 \pm 0.25$ & $0.99 \pm 0.07$ & $1.63 \pm 0.11$ \\
A549 & $>4$ & $1.88 \pm 0.09$ & $0.74 \pm 0.01$ \\
HepG2 & $3.13 \pm 0.20$ & $1.21 \pm 0.06$ & $4.21 \pm 0.12$ \\
WiDr & $2.67 \pm 0.14$ & $0.98 \pm 0.12$ & $0.72 \pm 0.09$ \\
CCD 841 CoN & $1.87 \pm 0.03$ & $1.21 \pm 0.02$ & $6.15 \pm 0.01$ \\
BJ & $2.48 \pm 0.15$ & $2.18 \pm 0.16$ & $5.73 \pm 0.36$ \\
\hline
\end{tabular}

When Table 1 is examined, it was seen that $\mathrm{IC}_{50}$ values (\%v/v) for ethanol (except A549 cell line) and DMSO ranged from 1.41 to 3.35 and 0.98 and 2.18, respectively. The most DMSO and ethanol sensitive cells were determined as WiDr and VMM917, while the most resistant cells were determined as BJ and A549, respectively. In consistent with our results, Forman et al. (1999) reported that DMSO and ethanol decrease the ATP level in HeLa cells at the concentrations of $1 \%$ and $5 \%(\mathrm{v} / \mathrm{v})$, respectively. Ben Trivedi et al. (1990) demonstrated that the DMSO concentrations higher than $0.5 \% \quad(\mathrm{v} / \mathrm{v})$ exhibits cytotoxic effect on HeLa cells in 72 -h treatment time, while Kade et al. (2016) demonstrated that the concentration of $50 \mathrm{mM}$ ethanol decreases the viability of HepG2 cells through decreasing intracellular GSH content and increasing intracellular ROS levels. Jamalzadeh et al. (2016) reported that DMSO and ethanol have cytotoxic effect on MCF-7 cells in a concentration dependent manner, and the $\mathrm{IC}_{50}$ values were calculated as $1.8 \%$ and $5 \%$ (v/v), respectively. No literature comparison has been made since there is no study showing the cytotoxic effect of ethanol and DMSO on VMM917, A549, WiDr, CCD 841 CoN and
BJ cell lines. However, cytotoxic effects of ethanol have been also evaluated on different cell lines, such as trophoblast (JEG3), murine macrophage (RAW-264.7), mouse hippocampal (HT22), Swiss 3T3 and human umbilical vein endothelium (HUVEC) and it has been demonstrated that the $\mathrm{IC}_{50}$ values of ethanol on the studied cells vary between $0.1 \%$ and $5 \%(\mathrm{v} / \mathrm{v})$ (Yeo et al. 2000; Clave et al., 2014; Casañas-Sánchez et al., 2016; Jamalzadeh et al., 2016). The mechanism of this cytotoxic effect of ethanol is explained by its property to increase the amount of reactive oxygen species (ROS), rate of apoptosis and to modulate the amount of many proteins, such as adenylate cyclase, protein kinase $\mathrm{C}$, protein tyrosine kinases and phospholipase C and D (Mikami et al., 1997; Yeo et al., 2000; Clave et al., 2014; Casañas-Sánchez et al., 2016). There are various report about the cytotoxic effect of DMSO on various cell lines, such as colon cancer (CaCo-2), retinal ganglion (RGC), astrocyte, human leukemic (THP1, U937, Jurkat, Molt-4) cell lines and it is reported that the $\mathrm{IC}_{50}$ values of DMSO on these cell lines vary between $0.5 \%$ to $3 \%$ (v/v) (Da Violante et al., 2002; Galvao et al., 2014; Yuan et al., 2014; Hajighasemi and Tajik, 2017; Singh et al., 2017). The 
mechanism of this cytotoxic effect of DMSO is explained by its property to interact with cell membrane and to modulate the metabolism, apoptosis and cell cycle (Singh et al., 2017; Yi et al., 2017).

\section{CONCLUSION}

This study is the first to demonstrate the cytotoxic concentration range of ethanol and DMSO in the VMM917, A549, WiDr, CCD $841 \mathrm{CoN}$ and BJ cell lines. The results reported here show that DMSO and ethanol have cytotoxic effects even at very low concentrations in these cell lines. Therefore, we believe that solvent concentrations should always remain the same when testing serial dilutions of compounds analyzed on these cell lines. It should also be noted that the response of each cell type to the solvent is different and that results obtained by solvent interactions in a cell type cannot be transferred to other cell types.

\section{Researchers Contribution Rate Declaration Summary}

The authors declare that they have contributed equally to the article.

\section{Conflicts of Interest Statement}

None of the authors had any financial or personal relationships with other individuals or organizations that might inappropriately influence their work during the submission process.

\section{REFERENCES}

Aliyazicioglu R, Demir S, Badem M, Sener SO, Korkmaz N, Demir EA, Ozgen U, Karaoglu SA, Aliyazicioglu Y, 2017. Antioxidant, antigenotoxic, antimicrobial activities and phytochemical analysis of Dianthus carmelitarum. Rec Nat Prod, 11(3): 270-284.

Aliyazicioglu Y, Demir S, Yaman SO, Sener SO, Demir EA, Aliyazicioglu R, Turan I, 2019. Phytochemical analysis of Dorycnium pentaphyllum and its antiproliferative effect on cervix cancer cells. $K S U$ J Agric Nat, 22(Suppl 2): 365-373.

Ben Trivedi A, Kitabatake N, Doi E, 1990. Toxicity of dimethyl sulfoxide as a solvent in bioassay system with HeLa cells evaluated colorimetrically with 3 (4,5-dimethylthiazol-2-yl)-2,5-diphenyl-tetrazolium bromide. Agric Biol Chem, 54(11): 2961-2966.

Berg KCG, Eide PW, Eilertsen IA, Johannessen B, Bruun J, Danielsen SA, Bjørnslett M, Meza-Zepeda LA, Eknæs M, Lind GE, Myklebost O, Skotheim RI, Sveen A, Lothe RA, 2017. Multi-omics of 34 colorectal cancer cell lines-a resource for biomedical studies. Mol Cancer, 16(1): 116.

Casañas-Sánchez V, Pérez JA, Quinto-Alemany D, Díaz M, 2016. Sub-toxic ethanol exposure modulates gene expression and enzyme activity of antioxidant systems to provide neuroprotection in hippocampal HT22 cells. Front Physiol, 7: 312.

Clave S, Joya X, Salat-Batlle J, Garcia-Algar O, Vall O, 2014. Ethanol cytotoxic effect on trophoblast cells. Toxicol Lett, 225(2): 216-221.

Da Violante G, Zerrouk N, Richard I, Provot G, Chaumeil JC, Arnaud P, 2002. Evaluation of the cytotoxicity effect of dimethyl sulfoxide (DMSO) on Caco2/TC7 colon tumor cell cultures. Biol Pharm Bull, 25(12): 1600-1603.

de Abreu Costa L, Henrique Fernandes Ottoni M, Dos Santos MG, Meireles AB, Gomes de Almeida V, de Fátima Pereira W, Alves de Avelar-Freitas B, Eustáquio Alvim Brito-Melo G, 2017. Dimethyl sulfoxide (DMSO) decreases cell proliferation and TNF- $\alpha, I^{2}-\gamma$, and IL-2 cytokines production in cultures of peripheral blood lymphocytes. Molecules, 22(11): E1789.

Demir S, Turan I, Aliyazicioglu Y, 2018a. Cytotoxic effect of Rhododendron luteum leaf extract on human cancer cell lines. KSU J Agric Nat, 21(6): 950-956.

Demir S, Turan I, Aliyazicioglu R, Ozer Yaman S, Aliyazicioglu Y, 2018b. Primula vulgaris extract induces cell cycle arrest and apoptosis in human cervix cancer cells. J Pharm Anal, 8(5): 307-311.

Demir S, Turan I, Aliyazicioglu Y, 2019a. Antioxidant properties of Primula vulgaris flower extract and its cytotoxic effect on human cancer cell lines. $K S U J$ Agric Nat, 22(1): 78-84.

Demir S, Turan I, Misir S, Aliyazicioglu Y, 2019b. Selective cytotoxic effect of Dorycnium pentaphyllum extract on human breast, liver, and lung cancer cells. KSU J Agric Nat, 22(3): 473-479.

Demir S, Yaman SO, Sener SO, Demir EA, Aliyazicioglu R, Ozgen U, Mentese A, Deger O, Aliyazicioglu Y, 2020. Dorycnium pentaphyllum extract has antiproliferative effect on human cervix and colon cancer cells. Nutr Cancer, 72(3): 504-512.

Ferreira D, Silva AP, Nobrega FL, Martins IM, Barbosa-Matos C, Granja S, Martins SF, Baltazar F, Rodrigues LR, 2019. Rational identification of a colorectal cancer targeting peptide through phage display. Sci Rep, 9: 3958.

Forman S, Kas J, Fini F, Steinberg M, Ruml T, 1999. The effect of different solvents on the ATP/ADP content and growth properties of HeLa cells. $J$ Biochem Mol Toxicol, 13(1): 11-15.

Galvao J, Davis B, Tilley M, Normando E, Duchen MR, Cordeiro MF, 2014. Unexpected low-dose toxicity of the universal solvent DMSO. FASEB J, 28(3): 13171330.

Gazdar AF, Girard L, Lockwood WW, Lam WL, Minna JD, 2010. Lung cancer cell lines as tools for biomedical discovery and research. $J$ Natl Cancer Inst, 102(17): 1310-1321.

Hajighasemi F, Tajik S, 2017. Assessment of cytotoxicity of dimethyl sulfoxide in human hematopoietic tumor cell lines. IJBC, 9(2): 48-53. 
Hebling J, Bianchi L, Basso FG, Scheffel DL, Soares DG, Carrilho MRO, Pashley DH, Tjäderhane L, de Souza Costa CA, 2015. Cytotoxicity of dimethyl sulfoxide (DMSO) in direct contact with odontoblast-like cells. Dent Mater, 31(4): 399-405.

Jamalzadeh L, Ghafoori H, Sariri R, Rabuti H, Nasirzade J, Hasani H, Aghamaali MR, 2016. Cytotoxic effects of some common organic solvents on MCF-7, RAW-264.7 and human umbilical vein endothelial cells. Avicenna J Med Biochem, 4(1): e33453.

Kade S, Herzog N, Schmidtke KU, Küpper JH, 2016. Chronic ethanol treatment depletes glutathione regeneration capacity in hepatoma cell line HepG2. J Cell Biotech, 1(2): 183-190.

Liu S, Gao G, Yan D, Chen X, Yao X, Guo S, Li G, Zhao Y, 2017. Effects of miR-145-5p through NRAS on the cell proliferation, apoptosis, migration, and invasion in melanoma by inhibiting MAPK and PI3K/AKT pathways. Cancer Med, 6(4): 819-833.

Mikami K, Haseba T, Ohno Y, 1997. Ethanol induces transient arrest of cell division $\left(\mathrm{G}_{2}+\mathrm{M}\right.$ block $)$ followed by $\mathrm{G}_{0} / \mathrm{G}_{1}$ block: dose effects of shortand longer-term ethanol exposure on cell cycle and cell functions. Alcohol Alcohol, 32(2): 145-152.

Misir S, Aliyazicioglu Y, Demir S, Turan I, Yaman SO, Deger O, 2018. Antioxidant properties and protective effect of Turkish propolis on t-BHPinduced oxidative stress in foreskin fibroblast cells. IJPER, 52(1): 94-100.

Misir S, Aliyazicioglu Y, Demir S, Turan I, Hepokur C, 2020. Effect of Turkish propolis on miRNA expression, cell cycle, and apoptosis in human breast cancer (MCF-7) cells. Nutr Cancer, 72(1):133-145.

Mosmann T, 1983. Rapid colorimetric assay for cellular growth and survival: application to proliferation and cytotoxicity assays. $J$ Immunol Methods, 65: 55-63.
Schäuble S, Klement K, Marthandan S, Münch S, Heiland I, Schuster S, Hemmerich P, Diekmann S, 2012. Quantitative model of cell cycle arrest and cellular senescence in primary human fibroblasts. PLoS One, 7(8): e42150.

Singh M, McKenzie K, Ma X, 2017. Effect of dimethyl sulfoxide on in vitro proliferation of skin fibroblast cells. J Biotech Res, 8: 78-82.

Timm M, Saaby L, Moesby L, Hansen EW, 2013. Considerations regarding use of solvents in in vitro cell based assays. Cytotechnology, 65: 887-894.

Turan I, Demir S, Kilinc K, Aliyazicioglu Y, Alver A, Misir S, Ozer Yaman S, Akbulut K, Mentese A, Deger O, 2017. Morus rubra extract induces $\mathrm{G}_{1}$ cell cycle arrest and apoptosis in human lung and prostate cancer cells. IJPER, 51(1): 51-58.

Turan I, Demir S, Kilinc K, Yaman SO, Misir S, Kara H, Genc B, Mentese A, Aliyazicioglu Y, Deger O, 2018. Cytotoxic effect of Rosa canina extract on human colon cancer cells through repression of telomerase expression. J Pharm Anal, 8(6): 394399.

Wu D, Bahaerguli K, Wu GR, Sheng L, 2010. Studies on the effect of DMSO as a solvent mediator on cell growth and viability. J Xinjiang Med Univ, 33: 489491.

Yeo EJ, Lim HK, Park SC, 2000. Effect of short-term ethanol on the proliferative response of Swiss 3T3 cells to mitogenic growth factors. Exp Mol Med, 32(3): 161-169.

Yi X, Liu M, Luo Q, Zhuo H, Cao H, Wang J, Han Y, 2017. Toxic effects of dimethyl sulfoxide on red blood cells, platelets, and vascular endothelial cells in vitro. FEBS Open Bio, 7: 485-494.

Yuan C, Gao J, Guo J, Bai L, Marshall C, Cai Z, Wang L, Xiao M, 2014. Dimethyl sulfoxide damages mitochondrial integrity and membrane potential in cultured astrocytes. PLoS One, 9(9): e107447. 